\title{
THEORIZING POLISH MIGRATION ACROSS EUROPE: PERSPECTIVES, CONCEPTS, AND METHODOLOGIES
}

\begin{abstract}
With the focus on the post-2004 mobility of Polish citizens, in this article we discuss two interrelated questions; namely, what are the most productive ways to theorize contemporary Polish migration, and what are the most fruitful methodologies aimed at understanding Polish migration and Poles on the move? In the first part of this article we unpack three interrelated theoretical frameworks: 'liquid migration,' 'regimes of mobility,' and 'transnationalism.' The methodological discussion in the second part of the article focuses mainly on outlining and contextualizing the most common approaches to migration phenomena. By critically introducing quantitative and qualitative methodologies, we explore and indicate the advantages of the ethnographic perspective and the merits and predicaments of research engagement in multiple sites.
\end{abstract}

Key words: Polish migration; 'liquid migration'; 'regimes of mobility'; transnationalism; multi-sited ethnography
ELŻBIETA GOŹDZIAK Georgetown University, Washington, United States

E-mail: emg27@georgetown.edu

MAREK PAWLAK

Jagiellonian University, Cracow, Poland E-mail: marek.pawlak@uj.edu.pl

This work was supported by a grant from National Science Centre. No competing interests have been declared.

Both authors participated in elaborating research ideas and writing the manuscript.

\footnotetext{
-...

The article was written as a part of research project "Mobile Lives, Immobile Realms? Female Mobility between Poland and Norway" financed by the National Science Centre (2014/14/M/ HS3/00842)
}

This is an Open Access article distributed under the terms of the Creative Commons Attribution 3.0 PL License (creativecommons.org/licenses/by/3.0/pl/), which permits redistribution, commercial and non-commercial, provided that the article is properly cited. (C) The Author(s) 2016.

Publisher: Institute of Slavic Studies, Polish Academy of Sciences [Wydawca: Instytut Slawistyki PAN] 
Streszczenie

Z naciskiem na mobilność obywateli polskich po przyłączeniu Polski do Unii Europejskiej w 2004 roku, w niniejszym artykule staramy się odpowiedzieć na dwa powiązane ze sobą pytania: jakie są najbardziej wydajne sposoby teoretyzowania współczesnej migracji polskiej oraz jakie są najbardziej owocne metody badawcze mające na celu zrozumienie polskiej migracji po akcesji do UE? W pierwszej części artykułu przedstawiamy więc trzy powiązane ze sobą koncepcje teoretyczne: „płynna migracja”, "reżimy mobilności" oraz transnarodowość. Dyskusja metodologiczna w drugiej części artykułu skupia się natomiast głównie na przedstawieniu najczęściej stosowanej metodyki i metodologii w badaniach zjawisk migracyjnych. Wprowadzając krytyczną perspektywę na temat ilościowych i jakościowych metod badawczych, staramy się wskazać wartość poznawczą perspektywy etnograficznej oraz wady i zalety etnograficznego zaangażowania badawczego w wielu miejscach.

Słowa kluczowe: polskie migracje; „płynna migracja”; "reżimy mobilności”; transnarodowość; etnografia wielostanowiskowa

\section{INTRODUCTION}

$\mathrm{P}$

oland has always been one of the largest migrant sending countries in Central and Eastern Europe. For more than a century it was a vast reservoir of migrant labor for many states in Western Europe and North America. Poland's accession to the European Union in May 2004, coupled with unrestricted entry into the United Kingdom, Sweden and Ireland and the subsequent opening up of all EU labor markets, caused one of the biggest emigration flows in the country's postwar history (see Gozdziak, 2016). On November 19, 2006, The New York Times reported that 800,000 Poles had left the country since Poland joined the EU. Citing data from the Polish Central Statistical Office, Kaczmarczyk and Okólski (2008) estimated that the number of Poles who lived abroad for at least two months tripled between early 2004 and early 2007 from approximately 180,000 to 540,000 bringing the number of Polish citizens working in Western Europe to an estimated 2.3 million (Kaczmarczyk \& Okólski, 2008). With this exodus Poland became one of the largest exporters of labor within the enlarged European Union (Gozdziak, 2014). The sudden and largely unexpected mass movement of Poles across Europe has significantly impacted the ways migration is theorized, researched, and understood.

Economists, demographers and sociologists continue to dominate migration studies. In Poland, the premier centers of migration studies are located within disciplines favoring analyses of quantitative data and are preoccupied with migration flows on a large scale. In this article, we depart from the macro-level statistical analyses and focus instead on theories and methodologies deployed by qualitative researchers, including those in our own discipline of anthropology. Anthropology, a discipline particularly sensitive to place, but at the same time comparative in its perspective, allows migration scholars to focus on the articulation between the place where migrants originate and the places where they go (Brettell, 2008), temporarily or permanently. The discipline also explores how people in local places respond to global processes while acknowledging the role of individual agency in reproduction, reinvention, and resistance to new constellations of power 
formed through new forms of mobility. Anthropology's focus on culture allows researchers to study the effects of new forms of mobility on new cultural forms and expressions, including religion, gender relations, contestation, post-socialist space, power relations in local governments, construction of race and ethnicity, and legal culture. While mobility per se has already been studied, migration scholars have not yet explored its effects in different social domains and localities on a micro scale by taking into account anthropological theory. As a comparative and cross-cultural science, anthropology has relied on typologies as a way to theorize similarity and difference (Brettell, 2008). In this instance, the anthropological lens enables researchers to compare and contrast the experiences of Polish migrants in different places.

Given the new Polish migration trajectories often involving multiple destinations, of import are also explorations of methodological issues involved in multi-sited research. Recent scholarship puts forth an argument that multi-sited research is valuable both methodologically and practically. As Coleman and Hellermann (2011) argue "(...) this creation of a dynamic which shifts perspective is not so different from anthropology itself - a discipline dependent on the cultivation of aesthetic, embodied, and intellectual sensibilities in relation to the world at large" (Coleman \& Hellermann, 2011: 2). Issues of the "construction of multi-site fields", in-depth engagement and complicity in the field, temporal and spatial arrangements, as well as "the dominant types of data in multi-site studies" (Hannerz 2003: 201-216) must be resolved in designing a study of 'liquid migrants.'

With the focus on the post-2004 mobility of Polish citizens, in this article we discuss two interrelated questions; namely, what are the most productive ways to theorize contemporary Polish migration, and what are the most fruitful methodologies aimed at understanding Polish migration and Poles on the move? In the first part of this article, we unpack three interrelated theoretical frameworks: 'liquid migration' (Black, Engbersen, Okólski, \& Panțîru, 2010; Engbersen, 2012), 'regimes of mobility' (Glick Schiller \& Salazar, 2013), and 'transnationalism' (Vertovec, 2009). The methodological discussion in the second part of the article focuses mainly on outlining and contextualizing the most common approaches to migration phenomena. By critically introducing quantitative and qualitative methodologies, which dominate Polish migration research, we explore the advantages of the ethnographic perspective as well as merits and predicaments of research engagement in multiple sites.

\section{EMIGRATION OR LIQUID MOBILITY?}

Despite empirical evidence to the contrary, Polish policy-makers debate contemporary Polish mobility across international borders within a traditional conceptual framework that regards such movement as unidirectional migration from country of origin to destination country that either ends with settlement, usually permanent or at the very least longterm, or in a permanent return home. Similar assumptions prevail in public discourses. When migrants return home, the return is often considered to be a result of a 'failed migration project' (Goździak, 2014). These conceptualizations do not fit contemporary trajectories of Polish migration, which became much more variegated after the EU enlargement and led to more diverse and floating populations. To paraphrase Bauman's (1999, 2005) work on 'liquid modernity,' Polish international migration has become 'liquid'. 
Bauman's concepts of 'liquid modernity' as well as the idea of 'settling into motion' are productive new ways to look at contemporary Polish migration. The deployment of this metaphor-'liquid migration'-is useful for understanding the dynamics of Polish migratory trends, especially during the period immediately following accession to the EU. The relatively stable migration patterns that marked the post-WWII period have changed considerably and became more complex, often transitory patterns of temporary settlement and fluid migration status (Engbersen, van der Leun \& de Boom, 2007). As Wallace (2002) argues, the post-1989 period witnessed an intensification of short-term, circular movements-what she terms mobility rather than migration-with Germany remaining a key destination country. Polish migrants, who for decades regarded the United States as the 'promised land' to settle in permanently, shifted their focus to Europe, because it is much more geographically accessible and therefore not necessarily a place of permanent settlement (Goździak, 2014). Polish migration took the form of 'pendulum' or 'circular' migration and, in some cases, transnational commuting (Goździak, 2016). This increase of short-term movements, no longer between just two countries (in the classic transnational framework) but often to several different countries in short successions, was "accompanied by a corresponding fall in permanent emigration" (Cyrus, 2006, p. 38).

These patterns fuel "the feeling that Europe as a whole has become much more fluid, and that the old rules and understandings of migration within the continent were being rewritten" (Burrell, 2009, p. 4). In this context 'fluidity' and 'liquidity' are apt metaphors that allow us to grasp the nature of the contemporary Polish migration or international migration more generally. As Bauman (2000, p. 13) asserts,

Throughout the solid stage of the modern era, nomadic habits remained out of favor. Citizenship went hand in hand with settlement, and the absence of 'fixed address' and 'statelessness' meant exclusion from the law-abiding and law-protected community and more often than not brought upon the culprits' legal discrimination, if not active prosecution. (...) the era of unconditional superiority of sedentarism over nomadism and the domination of the settled over the mobile is on the whole grinding fast to a halt. (...) In the fluid stage of modernity, the settled majority is ruled by the nomadic and exterritorial elite.

Indeed, the rules are changing and changing fast vis-à-vis young and educated mobile Poles; older, less educated Polish migrants, particularly those down on their luck, are still judged by the rules of the previous era (see Garapich, 2012; Czerniejewska \& Goździak, 2014).

The concept of 'liquid migration' corresponds well with the growing research on mobilities (Cresswell, 2006; Fincham, McGuinness, \& Murray, 2010; Urry, 2007; Sheller \& Urry, 2006), including studies addressing contemporary East-West movements (Black et al., 2010; Górny \& Ruspini, 2004; Okólski, 2012; Wallace \& Stola, 2001), and the increasing diversity of destination countries for Poles 'on the move' (Iglicka, 2001; Triandafyllidou, 2006). Interestingly, Urry (2000) refers in his article to another of Bauman's metaphors on 'gardening' (concerned with patterns, regularity, and ordering) versus 'gamekeeper' (regulating mobilities) states where he intimates that the former Eastern European societies used to be 'gardening' societies but are now returning to the 'gamekeeper' phase, characterized by fluid and complex networks and scapes.

Poles are now not only free to leave Poland but also are free to leave and to come back. These often multiple 'returns' demand more in-depth analysis. Such analysis can add nuances to and 'update' our understanding of return migration. It should be undertaken in the context of the broader literature on return migration and consider how similar 
or different the Polish case is vis-à-vis previous intra-European migration streams (see Brettell, 2003 on Portuguese migration) and other international migration flows (for example, US-Mexico), where the governments have also emphasized return, remittances, and investment.

Poles use their spatial mobility to adapt to the new context of post-communist spaces and $\mathrm{EU}$ enlargement. Rather than relying on transnational networking for improving their condition in the country of their settlement, many Poles after 2004 tended to settle within mobility, staying mobile as long as they could in order to improve or maintain a particular quality of life, enhance their professional qualifications, and pursue educational goals. Their experience of migration became their lifestyle, their leaving home and going away, paradoxically, became a strategy of staying at home, and, thus, an alternative to what international migration used to be considered: emigration or immigration (Czerniejewska \& Goździak, 2014). The liquidity of these post-socialist and post-accession mobility has received considerable academic attention, with a growing number of studies emphasizing the novelty of these East-West movements (e.g., King, 1993a, 1993b; Wallace \& Stola, 2001; Wallace, 2002; Górny \& Ruspini, 2004). In terms of Polish migration, the increasing diversity of destination countries has been stressed (Iglicka, 2001; Triandafyllidou, 2006). Our own reading of this literature indicates, however, that scholars tend to over-emphasize macro-level processes without an in-depth understanding of the effects of mobility and immobility on individuals, families, households, and localities, including the family and community members left behind. Lacking are also analyses of the intersection of gender and social class.

Burrell (2009) argues that there are two major points that need to be made about this upsurge of mobility within Europe at the end of the $20^{\text {th }}$ century. The first, in her view, "is tied closely to Fortier's (2006) assertion that Europe itself can be imagined through its migration flows - that the identity of the continent is (...) represented and reflected in the movement of bodies within it, and the ways in which these bodies are regulated" (Burrell, 2009, p. 4). She points out that it is tempting to link the increased freedom of movement of Eastern Europeans with the various commentaries about the 'return to Europe' of former East bloc countries. However, the gap between the rhetoric and the reality of 'returned' and 'restored' Europe is the second point that needs to be made. The divide between East and West is still clearly visible in the post-communist discourses of the 'backwardness' of Eastern Europe and in the treatment and experiences of those testing the limits of the new Europe, inequality of mobility, and access to social services, to name just a few persisting challenges.

The apparent pleasure stemming from being on the move is connected with the ambivalent feelings about permanent emigration expressed in the Polish public discourse. In official Polish historical narratives, migration has been often perceived in moral terms (Erdmans, 1992). As Garapich writes: "In Polish emigration ideology, political exile is seen as a sacred act in the fight for freedom and economic migration as a necessary evil, a manifestation of weakness or simply cowardice, egoism and an ambiguous act of turning away from the fate of the nation" (Garapich, 2007, p. 7). In popular parlance emigration was also often discussed as a burden, something one must endure. These narratives went hand-in-hand with issues of national identity. Ewa Morawska wrote about 'trudna polskość (difficult Polishness) when discussing national orientation of Polish migrants in Berlin in the early 2000s. "Trudna polskość," writes Morawska, "is the identity 'torn' by contradictory, positive and negative emotions toward one's own (Polish) group and 
by equally opposing attitudes toward 'others,' here, Germany/Germans and Europe/the European Union" (Morawska, 2003; see also Goździak, 2014).

As Czerniejewska and Goździak (2014) have shown, mobility as a strategy can be empowering and can result in 'success.' It can become a tool for social innovation and agency as well as an important dimension of social capital, provided that migrants retain control over their migration projects. Mobility, however, may also reflect increased dependencies, proliferation of precarious jobs, and labor exploitation that end in 'failure.' The mobilities paradigm (Cresswell, 2006; Sheller \& Urry, 2006; Urry, 2007) sheds new light on the power and purpose of critical social theory. The mobilities paradigm is substantively different, because, as Bücher and Urry suggest, "it enables the 'social world' to be theorized as a wide array of economic, social, and political practices, infrastructures and ideologies that all involve, entail or curtail various kinds of movements of people." The concept of mobilities "refers to this broad project of establishing a 'movement-driven' social sciences in which movement, potential movement and blocked movement, as well as voluntary/temporary immobilities, practices of dwelling and 'nomadic' placemaking are all conceptualized as constitutive of economic, social and political relations" (Bücher \& Urry, 2009, pp. 99-100). Let us then look a little closer at the regimes of the mobility paradigm.

\section{REGIMES OF MOBILITY}

Ever since the increased post-accession mobility of Poles, many people-researchers, politicians, and journalists alike-have wondered whether Polish migrants ought to be conceived as 'mobile workers' who will return home once they finish their jobs or as 'immigrants' who would settle down in their host countries (Friberg, 2012). Reality did not bear out these simple dualisms. Researchers who studied Polish migrants in the United Kingdom immediately after 2004 (e.g. Eade, Drinkwater, \& Garapich, 2006) found that

migrants had a wide range of different strategic and temporal adaptations, including single, short-term migration for the purpose of saving money to be spent upon return; circular migration alternating between work abroad and at home; open-ended plans for the future, seeking to maximize social and economic capital in both Poland and the UK; and intentions of permanent settlement and ambitions of social mobility in the UK (Friberg, 2012, p. 1590).

Writing about the 'new face of East-West migration in Europe,' Adrian Favell noted “East European migrants are (...) regional 'free movers' not immigrants and, with the borders open, they are more likely to engage in temporary circular or transnational mobility, governed by the ebb and flow of economic demand, than by long-term permanent immigration and asylum-seeking" (Favell, 2008, p. 703). The 'regimes of mobility' approach, which focuses not merely on the mobility, but rather on the complex interplay between mobility and immobility, localization and transnational connections, flows and roots (Glick Schiller \& Salazar, 2013), is a useful framework within which to study the mobility of Polish citizens. The growing popularity of the 'mobility paradigm' gives rise to several scientific questions such as: How do we theorize mobility as a feature of contemporary social life without lapsing into normalizing the mobility or the stasis? What is the impact of the development of globalizing socio-economic and political relations on the contextualization of mobility and immobility? How are global-spanning forces reflected within 
mobile and immobile lives? The importance of global political and economic forces is crucial for theoretical and practical understandings of contemporary mobilities. Additionally, by emphasizing the significant and complex interplay between macro (global) and micro (local) levels of both mobile and immobile social lives, a 'regimes of mobility' approach avoids methodological nationalism without neglecting the importance of a state, nation, or territory as imagined and regulatory agents.

The 'regimes of mobility' approach moves away from the binary thinking about migration and stasis by introducing both of these concepts as interconnected and interdependent. In other words, it neither normalizes the relationship between people and places nor naturalizes the very movement of people (Glick Schiller \& Salazar, 2013). Therefore, within the 'regimes of mobility' the movement and the stasis are relational and define each other, resulting in different reflections and incorporations of migratory experiences into particular senses of stability, fixity of place and the concepts of 'being home' and 'being away'. While mobility per se has already been studied, migration scholars have not yet explored its effects on different social domains and localities on a micro scale. In other words, the contemporary concern with mobility, while necessary, has made some scholars lose sight of the continued importance of place-based practices, relations between mobile and immobile subjects, as well as modes of consciousness for the (re)production of cultures and societies (Dahinden, 2010).

The European Union represents mobility "through discourse and praxis (...) as emancipatory 'social right' for EU citizens." However, within the EU discourse, mobility is unequivocally linked to the economy and, as Botterill (2011, p. 50) writes:

Rarely are cultural meanings of mobility referenced in EU policy, suggesting that official understandings are motivated by wider macro-economic concerns rather than everyday experiences of EU citizens. Moreover, the extent to which these 'enhanced' opportunities for mobility in the EU are acknowledged and enacted by young Polish people is yet to be fully examined.

Anne White (2014) further posits that migration histories in certain localities in Poland have contributed to a culture of migration wherein young people are being 'socialized into migration' and take it for granted that they can be geographically mobile at some point in their lives.

Kandel and Massey (2002) developed the term 'culture of migration' in their writing on Mexican-US migration. The concept describes a situation where 'absent migrants are always present' in the local social, cultural, and political life (Smith, 1995). Tim Erlick (2008) argues that the term applies to the migratory context of Poland as well, despite the fact that the scale of Polish migration is much lower than that of Mexican migration to the United States. Following the arguments presented by Horvath (2008) in his studies of mobile Romanian youth, Erlick (2008, pp. 1504-1505) posits that the concept of 'culture of migration' includes three categories of social phenomena, namely:

the transfer and exchange of cultural values, symbols, information, goods, and technologies; (...) the norms, values and ideologies of the community assessing migration and migrants, particularly the values attached to moving and staying; (...) and the social and 'cultural changes induced by the fact that societies have to adjust their ways of life to the absence of migrants from their communities.

In his own research, Erlick shows how temporal patterns of Polish migration affect social cohesion of the origin communities. He concludes that as more and more Poles stay abroad for longer periods of time, their absences "have a greater influence on life in the 
origin communities, in the sense that such communities have to make more adjustments to cope with the absence of key community members" (Erlick, 2008, p. 1515).

Almost twelve years have passed since Poland's accession to the EU, and researchers are beginning to notice new patterns of mobility (and immobility) among Polish citizens (White, 2014; Main, 2014). As Anne White (2014) points out, many of the Poles who have arrived in the UK since EU accession show signs of settling. Often this is a gradual process, especially for families with school-age children. In the next section, we discuss settlement and return through the lens of transnationalism.

\section{TRANSNATIONALISM}

In today's globalized world when travel between Poland and the United Kingdom, Ireland, Norway or any other European country is easy and relatively inexpensive, even those Poles that 'settled' outside Poland do not stay there without frequent visits to Poland. When work or childcare responsibilities do not allow for regular trips back and forth, Poles perform transnational activities in a myriad of different ways. While Poles enact transnationalism frequently, this theoretical perspective has rarely been applied in Polish research on mobility and cross-border migration (Krzyżanowski, 2008; Kuźma, 2004). International scholars examining Poles on the move have used this theoretical framework much more frequently. For example, Elizabetta Zontini finds transnationalism useful in challenging the assumed linearity of the migration process as a one-way journey by its acknowledging of the "fluid relationships between two or more countries." She argues that "transnationalism forces us to reconsider our understanding of households and families based on the idea of co-residency and physical unity and to take into account the possibility of spatial separation" (Zontini, 2004, p. 1114).

Writing about double returnees, Anne White (2014) discusses failed returns to Poland leading to settlement abroad within three types of transnationalism: transmigration, transnational practices, and transnational identities. Unlike Alejandro Portes (2001), who limits transnational practices to organized collective activities, Anne White adopts a very wide definition of the same concept. She acknowledges that "Although it is hard to disagree with scholars such as Boccagni (2012, p. 126) who argue that 'qualifying any form of identification with the country of origin as transnational would make little sense, since the adjective would be deprived of any discriminating power,' nonetheless it seems artificial to draw a line between collective and individual practices, since the latter have the same function of linking the migrant to the origin society" (White, 2014, p. 74). In addition, White deploys such concepts as "transnational consciousness" (Castles, 2002) or "transnational subjectivity" (Dahinden, 2009) to discuss transnational identities of Polish migrants in the United Kingdom. Louise Ryan (2010) uses the concept of transnationalism to study Polish transnational families. In her conceptualization of the term, transnationalism implies more than simply regular contact with the home country. Following Portes' criticism of transnationalism as a rather vague concept lacking a well-defined theoretical framework and analytical rigor (Portes, Guarnizo \& Landolt, 1999, p. 218), Ryan focuses on Polish migrants' narratives to study social and kinship networks of 'migrant families' (those relatives who have migrated) and their connections to relatives remaining in Poland. 
Among Polish researchers who find the concept of transnationalism useful in their research are Sylwia Urbańska and Izabella Main. Sylwia Urbańska $(2009,2015)$ analyzes the social phenomenon of Euro orphans (Eurosieroctwo)—children left behind by migrating mothers-within the framework of transnational mothering. She uses this analytical framework to critically analyze the concept of idealized motherhood that emphasizes the close relationship between mothering and the physical location of home. These conceptual frameworks provide a space within which Urbańska debates the moral panics that accompany transnational mothering and the criticisms put forth by social workers, educators, and child welfare experts who portray migrant parents-especially mothers-as irresponsible, greedy, and selfish (Urbańska, 2009, pp. 64-65). This is a very innovative way of analyzing public discourses grounded in an empirical vacuum. As the author underscores, the phenomenon of Euro orphans is both under-researched and under-theorized. Existing, very limited literature presents mainly the viewpoints of educators, social workers, psychologists, and lawyers. The perspectives of migrant parents are excluded from the analyses. Most data come from inadequate quantitative studies focused exclusively on tallying the number of children who have at least one parent working and are living abroad without in-depth qualitative analyses of the living conditions and the well-being of these children and youth. Urbańska also points out that the very term 'Euro orphans' has not been well-defined. Migrant parents are portrayed as deviants and their actions are discussed within deficit theory frameworks. This lack of theoretical underpinnings results in moral panics not in empirically grounded research.

In her research on Polish women in Barcelona, Spain, Izabella Main (2014) found both the concept of transnationalism and neo-nomadism very fruitful. All the women in her study lived transnational lives but not necessarily in the traditional and more limited sense of traversing two countries, the homeland and the destination country. Most lived in several international localities and retained important connections to Poland. For them these connections had considerable economic, socio-cultural and political values (Vertovec, 2001). Main also used the concept of neo-nomadism to categorize the women in her study. In keeping with D'Andrea notion of 'nomadology,' which rethinks "identity as always mobile and processual, partly self-construction, partly categorization by others, partly a condition, a status, a label, a weapon, a shield, a fund of memories," female identities are based on continuous metamorphosis (D'Andrea, 2007, p. 15). Main categorized Polish female migrants as global nomads, "since they migrated many times and some planned to migrate more in the future. For all of them, previous migratory experiences were significant and incorporated into their identities, performing different functions" (Main, 2014, p. 133). The growing transnational connections, driven by political and economic changes, have also greatly impacted research methodologies in migration studies.

\section{RESEARCHING MIGRATION IN MULTIPLE SITES}

Research on Polish migration is dominated by methods originating in economics, demography, and sociology, which tend to focus on macro analyses, essentialized categories, and calculable factors of mobility. Such approaches have their own merits and contribute to migration studies by mapping particular flows across space, presenting historical and contemporary migratory trends, and projecting migration trajectories. However, we argue 
that the existing domination of quantitative perspective may also be informed by the ongoing politicization of migration phenomena related to the public demands of 'calculating' and 'controlling' migration flows (see Castles, 2010, p. 1567). It may result in neglecting emplaced migrants' practices and narrowing the scope of research analysis.

In our opinion, it is crucial to employ a more collaborative approach to the study of migration, mobility, and migrants. Collaborative approaches, including community-based research, enables exploration of often concealed day-to-day routines of people on the move. These approaches may shed a new light on strategies of mobile lives. Hence, it is important to take a closer look at the existing methods of researching migration in Poland and, more generally, to explore the ethnographic approach in tackling contemporary migration phenomena in multiple sites.

\section{Quantitative and Qualitative Approaches to the Study of Polish Migration}

Migration scholarship in Poland is relatively new and its institutional origins may be traced to the early 1990s (see Iglicka, 2007). Poland's political and economic transition from communism to neoliberal capitalism, gradual openings of the borders, and emerging possibilities of movement resulted in growing scientific interest in migration phenomena. International research collaboration between scholars from eastern and western European countries began to flourish, and many important contributions were made to the emerging Polish migration scholarship.

The two dominant modes of researching Polish migration include quantitative and qualitative approaches. Polish scholars conducted numerous studies using statistical analysis (quantitative) and semi-structured interviews (qualitative) to better understand Polish migrants' strategies in destination countries and sending communities in Poland (Koryś, 2007, pp. 66-69). Researching migrants in receiving countries demanded appropriate methods and "[t]hough unsophisticated in methodological terms (usually based on a few dozens of semi-structured or in-depth interviews conducted by the authors themselves) these exploratory studies proved to be particularly efficient in studying irregular movements" (Koryś, 2007, p. 66). Among many studies on destination countries (see Koryś, 2007, p. 66), it is worth mentioning research conducted in Greece (Romaniszyn, 1994), surveys of Poles working in agriculture in Germany (Korczyńska, 2003), and research on undocumented Polish workers in Belgium (Grzymała-Kazłowska, 2001). These studies attempted to conceptualize different factors and conditions of migrant routes and labor strategies. According to Izabela Koryś (2007, pp. 66-67),

The extensive knowledge of the logic of circular migrations, strategies employed by emigrants (including the residence status infringements) and different types of costs (i.e. marginalization in the sending and receiving community) incurred by circular migration movements was considerably enriched through these type of studies.

An interesting idea of combining quantitative and qualitative methods is ethnosurvey, which originally was introduced by Douglas Massey (1987), but in the Polish context it was popularized by researchers affiliated with Centre of Migration Research in Warsaw (Jaźwińska, Łukowski, \& Okólski, 1997; cf. Koryś, 2007, p. 67; Jaźwińska, Filhel, Praszałowicz, Weinar, \& Kaczmarczyk, 2007, pp. 22-25). Ethnosurvey was employed in the studies on sending communities in Poland and aimed to "describe various migrants' types, motives, strategies and consequences of migration and, what is more, to formu- 
late an explanatory theory of the dominating character of outflow from Poland in the 1980s and 1990s" (Jaźwińska et al., 2007, p. 22). The main idea of ethnosurvey is to treat migration not as event, but rather a process involving different spatial and temporal dimensions. As Massey (1987, p. 1498) argues:

With few exceptions, international migration involves at least two cultures, two administrative systems, two governments, two political interests and, usually, two languages. As a result, statistics on international migration are generally the weakest area of demographic measurement, creating a scarcity of timely, accurate, and appropriate data.

Following Massey's idea, Polish migration scholars located their research in different regions in Poland in order to grasp the local diversity of migration. Consequently, they were able to explore differences between 'metropolitan' (Warsaw) and 'peripheral' areas in the context of migration flows (Jaźwińska et al., 2007, p. 22). The diversity of migration patterns clearly relates to regional migratory traditions. New migration flows of the $1980 \mathrm{~s}$ followed the 19th century routes: "the inhabitants of Podlasie (a north-eastern region of Poland) and Podhale (southern region) headed for the USA (...), whereas the Silesians (south-western region) for Germany" (Jaźwińska et al., 2007, p. 22). Conducting largescale ethnosurveys in sending communities also enhanced the existing understanding of shuttle migration, the role of social networks and migration capital, and introduced a more complex approach to migration than merely a statistical analysis.

The quantitative and qualitative methods definitely enriched the understanding of Polish migration flows across Europe. However, it also revealed serious shortcomings in employing such methods in migration research. First, by focusing chiefly on 'sample' and 'factors' rather than on empirical 'depth,' these methods lose sight of individual lives. It is then difficult to explore the agency of migrants, a crucial element of migration projects. Secondly, although quantitative and qualitative perspectives may shed some interesting light on migrants' formal livelihood strategies by mapping labor market participation, these perspectives hardly provide any significant insights into the informal ways that migrants live, work, or 'muddle through' unexpected life-situations. Thirdly and finally, both quantitative and qualitative approaches may lead to methodological pitfalls by overemphasizing the existing essentialized categories (e.g., nationality, ethnicity, race, or gender) thereby neglecting the internal social and cultural heterogeneity and dynamics. Consequently, it may turn research generalizations, which are important in producing scientific knowledge, into unproblematized remarks that reproduce stereotypes. the existing common knowledge. In our opinion, ethnography, with its emphasis on participant observation as well as reflexive and contextualized fieldwork perspectives, is an interesting and prolific method for conducting research on contemporary migration phenomena in multiple sites.

\section{The Distinctiveness of Ethnography: Merging the Global and the Local}

Migration scholarship in Poland continues to grow and is gradually changing under the influence of various theoretical and methodological approaches. Recently, Polish anthropologists began investigating migration phenomena and supplementing the migration scholarship with interesting and detailed analytical perspectives (see for example, Bielenin-Lenczowska, 2012; Bloch \& Goździak, 2010; Buchowski \& Schmidt, 2012; Czerniejewska, 2010; Garapich, 2008, 2009, 2012; Main, 2014; Pawlak, 2015a, 2015b). We argue 
that there is a kind of distinctiveness in the core of an ethnographic approach, which should be explored in order to understand its significance in migration studies.

Traditional ethnography typically situates a researcher in one field site for a long period of time. The researcher does not move across many spaces and gets to know one setting extremely well. Therefore, ethnography includes a long-term engagement, which becomes a fundamental vehicle for establishing a sense of social intimacy with field collaborators. As Mark-Anthony Falzon (2009, p. 1) argues: "Ethnography is an eclectic methodological choice which privileges an engaged, contextually rich and nuanced type of qualitative social research, in which fine grained daily interactions constitute the lifeblood of the data produced." In other words, ethnography is "rooted in the ideal of participant observation (to live, to some extent, as the 'natives' themselves do), itself based on relations of trust and a belief that data are produced in and of 'thick' interaction between researcher and researched" (Falzon, 2009, p. 1). The idea of 'thick' interactions and socalled 'deep hanging out' (Geertz, 2000, pp. 107-118) continue to be of a great methodological importance in anthropology. They are fundamental features of field collaboration, which could not be achieved otherwise.

The contemporary context of participant observation should, however, be understood as 'open-ended by definition.' The aim is to follow and treat events as entities with no defined borders. This approach allows for observing how different migrants function in different localizations. Furthermore, since the research 'objects' are to a large extent a product of the anthropologists themselves, the participant observation is conceptualized through joining streams of representations, which emerge from the discourses and practices of the analyzed local communities and by following migrants and their family members across diverse social spaces and diverse social groups (cf. Fortun, 2003). Participant observation is a rather demanding and time consuming approach and research method, and it demands long-term commitment from the researcher. However, it is also a significant aspect of the ethnographic approach and may shed a different light on the often 'taken for granted' socio-cultural strategies and practices of migrants.

Although participant observation remains an important element of ethnography, it had to be adjusted to the changing environment of a global world. George Marcus (1986, p. 165), writing about traditional conceptualizations of ethnography, argues "the two most common modes for self-consciously fixing ethnography in historic time are (...) the salvage mode and the redemptive mode." According to Marcus (1986, p. 165) "[i]n the salvage mode the ethnographer portrays himself as 'before the deluge,' so to speak." In other words, it means that "signs of fundamental change are apparent, but the ethnographer is able to salvage a cultural state on the verge of transformation." On the other hand, the 'redemptive mode' of ethnography presumes that "the ethnographer demonstrates the survival of distinctive and authentic cultural systems despite undeniable changes" (Marcus, 1986, p. 165). Both of these modes are insufficient and misconstrued ways to conduct anthropological fieldwork. One cannot practice ethnographic method in the contemporary world without exploring the interconnectedness of the global and the local, which together constitute the anthropological "field" (Marcus, 1986, 1995; cf. Gupta \& Ferguson, 1997; Rabinow, Marcus, Faubion, \& Rees, 2008).

The traditional ethnographic approach either neglected the significant impact of global forces or perceived them solely as a background for the emplaced socio-cultural practices of the micro level. However, the complexity of neoliberal transformations in our lives, as well as the interconnectedness of the global economy and politics, cannot be sim- 
ply described by classical ethnographic accounts. That particular field was conceptualized as closed, hermetic, and influence-proofed. The contemporary is characterized rather by shifts, changes, and flux, due to which anthropological research is by definition multidimensional and embedded within various regimes of discourses and practices (see Olwig \& Hastrup, 1997; Ong \& Collier, 2005).

This debate does not, however, mean that the particular field of anthropological inquires (e.g., 'locality,' 'culture,' 'region') should be discarded. On the contrary, these inquiries are still important spaces of social agency and actions towards global processes and phenomena - it is rather the approach and conceptualization that have been transformed. In other words, the premise for contemporary anthropological research is no more the 'order' of local and emplaced socio-cultural lives, but rather the 'non-order' that shows dynamics and linkage between macro and micro levels (see Olwig \& Hastrup, 1997, p. 7; cf. Amit, 2000). As Anna Lowenhaupt Tsing (2002, p. 465) argues:

\footnotetext{
the 'old' anthropology (...) describes cultures so grounded that they could not move out of place. This anthropology imprisons its objects in a cell; interconnection and movement in the form of 'global flows' are thus experienced as a form of liberation. Furthermore, these flows fit most neatly inside the discipline when, in deference to past teachers and conventions, the boundedness of past cultures goes unchallenged; global flows can then take the discipline, and the world, into a freer future.
}

Following such guidelines and new conceptualizations of ethnography, many anthropologists began to design their fieldwork in a rather innovative manner. Hence, researching migration became inseparably related with the idea of a researcher being engaged in several field sites (see for example, Gardner, 1995; Knowles, 2000; Olwig, 2007).

\section{Multisitedness in Ethnographic Approach to Migration}

Nowadays, it seems rather obvious that increasing transnational interconnections between and among people on the move require innovative data collection techniques and novel analytic approaches. The most common practice is multi-sited ethnography, a method of data collection that allows researchers to follow a topic or social problem through different field sites and analytically explore "transnational processes," "groups of people in motion," as well as "ideas that extend over multiple locations" (Marcus, 1995, pp. 95-117). In other words, "the methodological mandate 'to follow the people' as they travel between localities takes seriously the movement that constitutes the migratory process" (Fitzgerald, 2006, p. 5). In the context of contemporary migration flows and patterns, the multi-sited ethnographic approach allows us to explore interdependencies between global complexity and local entanglements. In other words, multi-sited ethnography follows a series of juxtapositions in which the global phenomena are not monolithic and external to the local - they are rather integral sites of parallel locations. Consequently, the 'world system' as we know is not merely a context or a framework of the research, but rather, it is embedded in multi-sited objects of the study (Falzon, 2009).

The emergence of multi-sited ethnography coincided with the economic and political transformations of the globalized world. Such processes as decolonization, the end of 'organized capitalism,' and the introduction of its neoliberal form greatly impacted both anthropological theorizations and fieldwork methodology. The previously existing concept of ethnographically 'being there' has been reconfigured, critically reflected upon, and 
scrutinized across the discipline. At the same time, the idea of studying different and multiple sites gradually started to be an important methodological approach, particularly among anthropologists exploring the field of migration studies. However, besides its obvious merits for migration research, one may also indicate that 'multi-sited' ethnography has its flaws and is often misunderstood and misused by various researchers. In order to avoid methodological errors, it is necessary to take a closer look on the origins of 'multisitedness' and its transformations in anthropological conduct.

The existing flows of people, things and ideas demand new multiple explorations in multiple sites (see for example, Appadurai, 1986; Hannerz, 1996, 2003; Levitt, 2007; MacGaffey \& Bazenguissa-Ganga, 2000; Stoller, 2002; cf. Horst, 2009, p. 120). Differing from traditional ethnography, multi-sited ethnography follows a research topic across numerous spaces for shorter periods of time. The differences between traditional and multisited ethnography can be understood visually as following a topic across one space (vertically) or multiple spaces (horizontally). Marcus (1995, pp. 106-110) distinguishes several examples of this approach, namely following the people, the thing, the metaphor, the plot, the story or allegory, the life or biography, and the conflict. As Marcus (2009, p. 181) later argues:

There is something about the way traditional units or objects of study-for example culture, cultures, community, subjects-present themselves nowadays, combined with the near revolution in theory, that has immensely complicated the way these classic terms are understood operationally, and that makes one want to conceive of Malinowskian ethnography within timespace frames that instill pragmatic doubt about its very feasibility under the current regime of research norms.

His idea of a new methodological approach to the contemporary social, cultural, political, and economic phenomena is therefore the result of the incompatibility of Malinowskian scenery, the influx of the world, and the conceptual changes within anthropology.

The introduction of this 'new' perspective evoked a series of critical remarks in anthropological scholarship. The specifics of research design and the methodological 'toolbox' that is needed in multi-sited fieldwork raised crucial questions of temporal, spatial and scientific matter among many anthropologists. According to Falzon (2009, p. 7),

The discussion on multi-sited ethnography revolves around the idea that it may well be a contradiction in terms. That is, there exists a preoccupation that, while there is much to be said for researching spatially dispersed objects, a program that proposes to be more routes than roots (see Clifford, 1997) could well end up throwing out the proverbial bathwater and robbing ethnography of its central tenets as presented earlier.

Perhaps the most important questions are on the basic understanding of 'field', its scientific recognition, and anthropological exploration: How many fields constitute an idea of 'multisitedness?' Is it possible to maintain an in-depth engagement while doing fieldwork in multiple sites? How much time does one need to spend in the field in order to achieve a sense of anthropological intimacy and familiarity?

The predicaments of multi-sited ethnography may be pinned down to three crucial 'charges' (Falzon, 2009, pp. 7-13). Firstly, there is a rather justified concern that such approach may lead to a lack of ethnographic 'depth' and 'thickness.' As many anthropologists argue, to achieve a sense of empirical 'depth' takes time and is hard to achieve within a multi-sited approach. Depth is nothing else than 'thick description', which offers rich ethnographic understandings of explored phenomena. Lack of depth is therefore 
"thought to be the major enemy of the multi-sited program. Briefly put, given that this type of research implies moving around and 'following' horizontally, there is little time for staying put and 'following' vertically" (Falzon, 2009, p. 7). Secondly, there is a criticism that concerns the 'abdication of ethnographic responsibility,' which means that the complex relationships between the researcher and the researched in the field are neglected or assumed to be of secondary importance. These critiques argue that the idea of just 'following people' puts the researcher in 'danger' of losing the key ethnographic sense of reflexivity, positionality, complicity, and collaboration in their fieldwork. Thirdly, there is concern that multisitedness implies the 'latter-day holism' since "it purports to study the 'world system'" (Falzon, 2009, p. 12).

The existing criticism has its merits and cannot be easily discarded. It may be particularly complied with research which assumes that multi-sited ethnography is merely a series of 'qualitative semi-structured interviews' conducted in different geographical locations. There is a growing tendency in migration scholarship to use multi-sited ethnography interchangeably with qualitative research. However, this method is not about 'interviews' and 'surveys' or the 'multiplication of the number of field sites' (Horst, 2009, p. 120). Such understanding deprives multi-sited ethnography from the ethnography itself and exposes researchers to methodological criticism. As Ester Gallo (2009, p. 89) points out: "the importance of multi-sited ethnography is rooted in the recognition that the 'field' of ethnographic inquiry is not simply a geographical place waiting to be entered, but rather a 'conceptual space' whose meanings and confines are continuously negotiated by the ethnographer and their informants."

It is precisely in such 'negotiation of meanings and confines' that ethnography-participant observation, the global, and the local-plays a pivotal role. In other words, "the success of multi-sited research on migration has often been associated with the capacity strategically to select the 'right' sites, in order to limit the dangers of stretching already limited time and resources" (Gallo, 2009, p. 89). Unfortunately, due to existing constraints within the regimes of academia (publish or perish), economics (funding schemes), and politics (controlling migration), many scholars follow the easier and feasible way of conducting a research of 'now and then' and 'in between' lives (Hannerz, 2003, pp. 212-213; cf. Horst, 2009, p. 121). As Cindy Horst (2009, p. 121) argues,

these more mundane issues may be far less visible in the debate but are no less important; although it is necessary to have an understanding of the methodological reasons for the development of multi-sited approaches, these practical explanations and implications need to be explored as well.

In order to actually follow the method of multi-sited ethnography, one needs to merge the micro (local) and macro (global) levels into one complex unit of analysis and be open to (and follow) the emerging new research contexts, phenomena, and ideas in the field. In other words, multisitedness in ethnography, "implies the articulation of a priori selected geographical sites with the indeterminacy of what these sites will eventually turn out to be" (Gallo, 2009, p. 89). Such approach is nothing new in anthropological fieldwork and the idea of being open to serendipity and unpredictability in the field has been well known for generations. However, "multi-sited ethnography implies not only the capacity of being ready to put into question theoretical assumptions and research expectations that precede fieldwork; it also requires the researcher to put into question previous sites of ethnographic inquiry in light of new ones" (Gallo, 2009, p. 89). 
It seems obvious that migration phenomena must be studied in multiple sites. After all, one needs to explore "different types of 'motion'" (Fitzgerald, 2004, p. 2) and "study networks" (Hannerz, 2003, p. 21), which obviously are crucial aspects of contemporary migration (see Horst, 2009, p. 120). It is precisely multi-sited ethnography that "enable us to study the field as a network of localities which are linked to each other through various types of flows" (Horst, 2009, p. 120). However, it does not mean that anthropology should discard participant observation and 'in-depth' engagement in favor of short field visits, semi-structured interviews, and surveys. After all, most migrants do not stay in a destination place just for a few days (and if they do, it is rather a case of their migratory strategy, which should also be explored with a sense of complicity and collaboration between the researcher and the researched).

It is rather accurate, when Falzon (2009, pp. 1-2) points out that "the essence of multi-sited research is to follow people, connections, associations, and relationships across space (because they are substantially continuous but spatially non-contiguous)." He further argues that the "research design proceeds by a series of juxtapositions in which the global is collapsed into and made an integral part of parallel, related local situations, rather than something monolithic or external to them" (Falzon, 2009, p. 2). But, if we conceptualize multi-sited ethnography as it should be meant, then "perhaps the main difference between single- and multi-sited approaches is language. The former talks about containing, the latter about extending" (Falzon, 2009, p. 13).

\section{CONCLUSIONS}

Poland's accession to the European Union and Schengen Area has had a great impact in Polish migration scholarship on traditional conceptualizations of categories such as emigration, immigration, and return. These events influenced both theoretical and methodological aspects of researching migration. After all, in Polish scholarship migration was usually perceived as a unidirectional phenomenon involving people moving from sending to receiving country, with the end stage being integration into the host society. Such an approach had crucial consequences for theoretical and practical understandings of migration, because it imposed 'ethnic lenses' and methodological nationalism. Obviously, the research assumption about the congruence between the nation, the state, and society is flawed and misleading, similar to conceptualizing them as 'natural' ways of social organizations.

However, it seems that the very category of the 'national' incessantly plays a rather pervasive role in both the public and the private spheres. When a Frenchman moves from Paris to Geneva to take a new job at the International Organization for Labor, or a Brit moves from London to Rome to work at the World Food Program, they are called expats, and their movement is described as employment mobility. When a Polish nurse moves to London or a Polish plumber seeks employment in Paris, however, they are always conceptualized as labor migrants. A couple of years ago, a UK Government minister caused anger because he compared Britons who buy holiday homes abroad to Eastern Europeans planning to live in the United Kingdom. "Calling a Western European who lives in another country a 'migrant' often triggers very defensive reactions," writes Oana Ramocea (2013), "because the term 'migrant' has become so associated with illegality including 
system abuse and criminality." Yet, since 2004 when Poland joined the European Union, Polish citizens gained the right to employment in most European countries. Moving and working in London, Dublin, or Berlin, they are not violating any laws but simply exercising their fundamental rights to free movement and employment within the EU family of nation-states.

If Poles are not violating any laws by moving between countries, what processes and imaginaries are at work in order for them to continue to be perceived as outsiders rather than members of the EU family? We posit that the process of othering East/Central Europe and its inhabitants might be responsible for the continued perception of Eastern Europeans as migrants rather than mobile individuals. Interestingly, there is a sense of paradox in such ideological claims and valorizations. By using the spatial mobility and following pragmatic choices and economic opportunities, many Polish migrants, as the EU citizens, make the most of the given context of freedom of movement for workers. Although, the existing neoliberal discourse in Europe presents the mobility of its citizens (and only their mobility) as a rather positive trait-almost synonymous to freedom, flexibility, and change-there is a sense of othering one mobilities at the cost of others (cf. Pawlak, 2015a).

\section{BIBLIOGRAPHY}

Amit, V. (Ed.). (2000). Constructing the field: Ethnographic fieldwork in the contemporary world. London: Routledge.

Appadurai, A. (1986). The social life of things: Commodities in cultural perspective. Cambridge: Cambridge University Press. http://dx.doi.org/10.1017/CBO9780511819582

Bauman, Z. (1999). In search of politics. Stanford, CA: Stanford University Press.

Bauman, Z. (2000). Liquid modernity. Cambridge: Polity.

Bauman, Z. (2005). Liquid life. Cambridge: Polity.

Bielenin-Lenczowska, K. (2012). Keeping feet in two worlds?: Everyday experiences of female migrants from Macedonia to Italy. In P. Hristova (Ed.), Migration and identity: Historical, cultural and linguistic dimensions of mobility in the Balkans. Sofia: Paradigma.

Black, R., Engbersen, G., Okólski, M., \& Panțîru, C. (Eds.). (2010). A continent moving west?: EU enlargement and labour migration from Central and Eastern Europe. Amsterdam: Amsterdam University Press.

Bloch, N., \& Goździak, E. M. (Eds.). (2010). Od gości do sąsiadów: Integracja cudzoziemców spoza Unii Europejskiej w Poznaniu w edukacji, na rynku pracy i w opiece zdrowotnej. Poznań: CeBaM, UAM.

Boccagni, P. (2012). Rethinking transnational studies: Transnational ties and the transnationalism of everyday life. European Journal of Social Theory, 15(1), 117-132. http:// dx.doi.org/10.1177/1368431011423600

Botterill, K. (2011). Mobility and immobility in the European Union: Experiences of young Polish people living in the UK. Studia Migracyjne, (1), 47-70.

Brettell, C. (2003). Anthropology and migration: Essays on transnationalism, ethnicity, and identity. Walnut Creek, Calif: Altamira.

Brettell, C. (2008). Migration theory: Talking across disciplines. New York: Routledge. 
Bücher, M., \& Urry, J. (2009). Mobile methods and the empirical. European Journal of Social Theory, 12(1), 99-116. http://dx.doi.org/10.1177/1368431008099642

Buchowski, M., \& Schmidt, J. (Eds.). (2012). Imigranci: Między integracją a izolacją. Poznań: Wydawnictwo Nauka i Innowacje.

Burrell, K. (Ed.). (2009). Polish migration to the UK in the "new" EU after 2004. Farnham: Ashgate.

Castles, S. (2002). Migration and community formation under conditions of globalization. International Migration Review, 36(4), 1143-1168. http://dx.doi. org/10.1111/j.1747-7379.2002.tb00121.x

Castles, S. (2010). Understanding global migration: A social transformation perspective. Journal of Ethnic and Migration Studies, 36(10), 1565-1586. http://dx.doi.org/10.1080/ 1369183X.2010.489381

Clifford, J. (1997). Routes: Travel and translation in the late twentieth century. Cambridge: Harvard University Press.

Clifford, J., \& Marcus, G. E. (Eds.). (1986). Writing culture: The poetics and politics of ethnography. Berkeley: University of California Press.

Coleman, S., \& Hellermann, P. von. (2011) Multi-sited ethnography: Problems and possibilities in the translocation of research methods. New York: Routledge.

Cresswell, T. (2006). On the move: Mobility in the modern world. London: Routledge.

Cyrus, N. (2006). Recent Polish immigrants in the UK. In A. Triandafyllidou (Ed.), Contemporary Polish migration in Europe: Complex patterns of movement and settlement. Washington, DC: Edward Mellen.

Czerniejewska, I. (2010). Migrant pupils in Poznań: An exploratory ethnographic research. Ethnologia Polona, 31-32, 261-280.

Czerniejewska, I., \& Goździak, E. M. (2014). Aiding defeated migrants. International Migration, 52(1), 87-99. http://dx.doi.org/10.1111/imig.12145

Dahinden, J. (2009). Are we all transnationals now?: Network transnationalism and transnational subjectivity: the differing impacts of globalization on the inhabitants of a small Swiss city. Ethnic and Racial Studies, 32(8), 1365-1386. http://dx.doi. org/10.1080/01419870802506534

Dahinden, J. (2010). The dynamics of migrants' transnational formations: Between mobility and locality. In R. Bauböck \& T. Faist (Eds.), Diaspora and transnationalism: Concepts, theories and methods (pp. 51-71). Amsterdam: Amsterdam University Press.

D'Andrea, A. (2007). Global nomads: Techno and New Age as transnational countercultures in Ibiza and Goa. London: Routledge.

Eade, J., Drinkwater, S., \& Garapich, M. (2006). Class and ethnicity: Polish migrants in London. Guildford: University of Roehampton, Centre for Research on Nationality, Ethnicity, and Multiculturalis.

Engbersen, G. (2012). Migration transitions in an era of liquid migration: Reflections on Fassmann \& Reeger. In M. Okólski (Ed.), Europe: The continent of immigrants: Trends, structures and policy implications (pp. 91-105). Amsterdam: Amsterdam University Press.

Engbersen, G., van der Leun, J., \& de Boom, J. (2007). The fragmentation of migration and crime in the Netherlands. Crime and Justice, 35(1), 389-452. http://doi. org/10.1086/650189

Erdmans, M. P. (1992). The social construction of emigration as a moral issue. Polish American Studies, 49(1), 5-25. 
Erlick, T. (2008). The influence of migration on origin communities: Insights from Polish migrations to the west. Europe-Asia Studies, 60(9), 1503-1517. http://dx.doi. org/10.1080/09668130802362243

Falzon, M.-A. (2005). Cosmopolitan connections: The Sindhi diaspora 1860-2000. New Delhi: Oxford University Press.

Falzon, M.-A. (Ed.). (2009). Multi-sited ethnography: Theory, praxis and locality in contemporary research. Aldershot: Ashgate.

Favell, A. (2008). The new face of east-west migration in Europe. Journal of Ethnic and Migration Studies, 34(5), 701-716. http://dx.doi.org/10.1080/13691830802105947

Fincham, B., McGuinness, M., \& Murray, L. (2010). Mobile methodologies. Basingstoke: Palgrave Macmillan.

Fitzgerald, D. (2004). Ethnographies of migration. Theory and Research in Comparative Social Analysis, (19). http:// repositories.cdlib.org/uclasoc/trcsa/19

Fitzgerald, D. (2006). Towards a theoretical ethnography of migration. Qualitative Sociology, 29(1), 1-24. http://dx.doi.org/10.1007/s11133-005-9005-6

Fortier, A. M. (2006). The politics of scaling, timing and embodying: Rethinking the 'New Europe'. Mobilities, 1(3), 313-331. http://dx.doi.org/10.1080/17450100600915992

Fortun, K. (2003). Ethnography in/of/as open systems. Reviews in Anthropology, 32(2), 171-190. http://dx.doi.org/10.1080/00988150390197695

Friberg, J. H. (2012). The States of migration: From going abroad to settling down: Postaccession Polish migrant worker in Norway. Journal of Ethnic and Migration Studies, 38(10), 1589-1605. http://dx.doi.org/10.1080/1369183X.2012.711055

Gallo, E. (2009). In the right place at the right time? Reflections on multi-sited ethnography in the age of migration. In M.-A. Falzon (Ed.), Multi-sited ethnography: Theory, praxis and locality in contemporary research (pp. 87-102). Aldershot: Ashgate.

Garapich, M. (2007). Odyssean refugees, migrants and power - construction of 'other' within the Polish 'community' in the UK. In D. Reed-Danahay \& C. Brettell (Eds.), Immigration and citizenship in Europe and the U.S.: Anthropological perspectives. Rutgers University Press.

Garapich, M. (2008). The migration industry and civil society: Polish immigrants in the United Kingdom before and after EU enlargement. Journal of Ethnic and Migration Studies, 34(5), 735-752. http://dx.doi.org/10.1080/13691830802105970

Garapich, M. (2009). Migracje, społeczeństwo obywatelskie i władza: Uwarunkowania stowarzyszeniowości etnicznej i rozwoju społeczeństwa obywatelskiego wśród polskich emigrantów w Wielkiej Brytanii. In M. Duszczyk \& M. Lesińska (Eds.), Wspótczesne migracje: Dylematy Europy i Polski (pp. 39-69). Warszawa: Wydawnictwo Petit.

Garapich, M. (2012). Between cooperation and hostility - constructions of ethnicity and social class among Polish migrants in London. Studia Sociologica, 29-44.

Gardner, K. (1995). Global migrants, local lives: Migration and transformation in rural Bangladesh. Oxford: Oxford University Press.

Geertz, C. (2000). Available light: Anthropological reflections on philosophical topics. Princeton, NJ: Princeton University Press.

Glick Schiller, N., \& Salazar, N. B. (2013). Regimes of mobility across the globe. Journal of Ethnic and Migration Studies, 39(2), 183-200. http://dx.doi.org/10.1080/136918 3X.2013.723253 
Górny, A., \& Ruspini, P. (2004). Migration in the new Europe: East-West revisited. Basingstoke, Hampshire: Palgrave.

Goździak, E. M. (2016). Biała emigracja: Variegated mobility of Polish care workers. Social Identities, 22(1), 26-43. http://dx.doi.org/10.1080/13504630.2015.1110354

Goździak, E. M. (2014) Polish Migration after the Fall of the Iron Curtain. International Migration 52(1): 1-3.

Grzymała-Kazłowska, A. (2001). Polscy nielegalni pracownicy w Belgii. CMR Working Papers, (41).

Gupta, A., \& Ferguson, J. (1997). Anthropological locations: Boundaries and grounds of a field science. Berkeley: University of California Press.

Hannerz, U. (1996). Transnational connections: Culture, people, places. London: Routledge.

Hannerz, U. (2002). Flows, boundaries and hybrids: Keywords in transnational anthropology. Working paper, Transnational Communities Programme, University of Oxford.

Hannerz, U. (2003). 'Being there ... and there ... and there!': Reflections on multi-site ethnography. Ethnography, 4(2), 201-216. http://dx.doi.org/10.1177/14661381030042003

Horst, C. (2009). Expanding sites: The question of 'depth' explored. In M.-A. Falzon (Ed.), Multi-sited ethnography: Theory, praxis and locality in contemporary research (pp. 119-133). Aldershot: Ashgate.

Horvath, I. (2008). Culture of migration of the rural Romanian young people. Journal of Ethnic and Migration Studies, 34(5), 771-786. http://dx.doi. org/10.1080/13691830802106036

Iglicka, K. (2001). Poland: Between geopolitical shifts and emerging migratory patterns. CMR Working Papers, (42). http://www.migracje.uw.edu.pl/publ/577/

Iglicka, K. (2007). A note on rebirth of migration research in Poland after 1989. In A. Kicinger \& A. Weinar (Eds.), State of the art of the migration research in Poland (pp. 1217). Warszawa. (CEFMR Working Paper 1/2007)

Jaźwińska, E., Filhel, A., Praszałowicz, D., Weinar, A., \& Kaczmarczyk, P. (2007). Studies of mechanisms of emigration from Poland after 1989. In A. Kicinger \& A. Weinar (Eds.), State of the art of the migration research in Poland (pp. 18-36). Warszawa. (CEFMR Working Paper 1/2007)

Jaźwińska, E., Łukowski, W., \& Okólski, M. (1997). Przyczyny i konsekwencje emigracji z Polski. CMR Working Papers, (7).

Kaczmarczyk, P., \& Okólski, M. (2008). Polityka migracyjna jako instrument promocji zatrudnienia i ograniczania bezrobocia. Warszawa: OBM UW. http://www.migracje. uw.edu.pl/publ/191/

Kandel, W., \& Massey, D. S. (2002). The culture of Mexican migration: A theoretical and empirical analysis. Social Forces, 80(3), 981-1004. http://dx.doi.org/10.1353/ sof.2002.0009

King, R. (Ed.). (1993a). Mass migrations in Europe: The legacy and the future. London: Belhaven Press.

King, R. (Ed.). (1993b). The new geography of European migrations. London: Belhaven Press.

Knowles, C. (2000). Here and there: Doing transnational fieldwork. In V. Amit (Ed.), Constructing the field: Ethnographic fieldwork in the contemporary world (pp. 54-70). London: Routledge. 
Korczyńska, J. (2003). Sezonowe wyjazdy zarobkowe Polaków do Niemiec. Warszawa: Scholar.

Koryś, I. (2007). Methods of migration research in Poland - critical overview. In A. Kicinger \& A. Weinar (Eds.), State of the art of the migration research in Poland (pp. 6670). Warszawa. (CEFMR Working Paper 1/2007)

Krzyżanowski, L. (2008). Kapitał społeczny i aspiracje zawodowe transmigrantów w kontekście kultury migracyjnej małej społeczności wiejskiej. In A. Śliz (Ed.), Społeczności lokalne: Postawy migracyjne młodych Polaków (pp. 135-151). Opole: Wydawnictwo Uniwersytetu Opolskiego i Polskie Towarzystwo Socjologiczne.

Kuźma, E. (2004). Polish immigrants in Brussels: The emergence of the new social phenomenon. Conference paper Working Group on International Migration in Europe, Rome 24-27 November, 2004.

Levitt, P. (2007). God needs no passport: Immigrants and the changing American religious landscape. New York: The New Press.

Lowenhaupt Tsing, A. (2002). The global situation. In J. X. Inda \& R. Rosaldo (Eds.), The anthropology of globalization: A reader (pp. 453-485). Oxford: Blackwell Publishers.

MacGaffey, J., \& Bazenguissa-Ganga, R. (2000). Congo-Paris: Transnational traders on the margins of the law. London: James Currey.

Main, I. (2014). High mobility of Polish women: The Ethnographic Inquiry of Barcelona. International Migration, 52(1), 130-145. http://dx.doi.org/10.1111/imig.12119

Marcus, G. (1986). Contemporary problems of ethnography in the modern world system. In G. Marcus \& J. Clifford (Eds.), Writing culture (pp. 165-193). Berkeley: University Press.

Marcus, G. (1995). Ethnography in/of the world system: The emergence of multi-sited ethnography. Annual Review of Anthropology, 24, 95-117. http://dx.doi.org/10.1146/ annurev.an.24.100195.000523

Marcus, G. (2009). Multi-sited ethnography: Notes and queries. In M.-A. Falzon (Ed.), Multi-sited ethnography: Theory, praxis and locality in contemporary research (pp. 181196). Aldershot: Ashgate.

Massey, D. S. (1987). The ethnosurvey in theory and practice. International Migration Review, 21(4), 1498-1522. http://dx.doi.org/10.2307/2546522

Morawska, E. (2003). National identities of Polish (im)migrants in Berlin: Four varieties, their correlates and implications. In W. Spohn \& A. Triandafyllidou (Eds.), Europeanisation, national identities and migration changes in boundary constructions between Western and Eastern Europe (pp. 171-191). London: Routledge.

Okólski, M. (2012). European immigrations: Trends, structures and policy implications. Amsterdam: Amsterdam University Press.

Olwig, K. F. (2007). Caribbean journeys: An ethnography of migration and home in three family networks. Durham: Duke University Press.

Olwig, K. F., \& Hastrup, K. (Eds.). (1997). Siting culture: The shifting anthropological object. London: Routledge.

Ong, A., \& Collier, S. J. (Eds.). (2005). Global assemblages: Technology, politics, and ethics as anthropological problems. Malden: Blackwell Publishing.

Pawlak, M. (2015a). Othering the self?: National identity and social class in mobile lives between Poland and Norway. In M. Buchowski, H. Červinková, \& Z. Uherek (Eds.), Rethinking ethnography in Central Europe (pp. 23-40). New York: Palgrave Macmillan. 
Pawlak, M. (2015b). Recognizing the national identity: Cultural intimacy and the Polish migration to Norway. Prace Etnograficzne, 43(3).

Portes, A. (2001). Introduction: The debates and significance of immigrant transnationalism. Global Networks, 1(3), 181-193. http://dx.doi.org/10.1111/1471-0374.00012

Portes, A., Guarnizo, L. E., \& Landolt, P. (1999). The study of transnationalism: pitfalls and promise of an emergent research field. Ethnic and Racial Studies 22: 217-237.

Rabinow, P., Marcus, G. E., Faubion, J. D., \& Rees, T. (2008). Designs for an anthropology of the contemporary. Durham: Duke Press. http://dx.doi.org/10.1215/9780822390060

Ramocea, O. (2013). East European migrants vs. West European expats - British influence, 19 Nov. 2013. New Europeans net. Retrieved 8 February 2016, from https:// neweuropeans.net/article/115/east-european-migrants-vs-west-european-expats-british-influence-19-nov-2013

Romaniszyn, K. (1994). Polacy w Grecji. Studia Polonijne, 16, 7-98.

Ryan, L. (2010). Becoming Polish in London: negotiating ethnicity through migration. Social Identities 13(3): 359-376.

Sheller, M., \& Urry, J. (2006). The new mobilities paradigm. Environment and Planning A., 38(2), 207-226. http://dx.doi.org/10.1068/a37268

Smith, R. C. (1995). Los Ausentes Siempre Presentes: The imagining, making and politics of a transnational community (Unpublished Ph.D. Thesis). Columbia University, Politics Science.

Stoller, P. (2002). Money has no smell: The Africanization of New York City. Chicago: The University of Chicago Press.

Triandafyllidou, A. (2006). Contemporary Polish migration in Europe. Lewiston, NY: Mellen Press.

Urbańska, S. (2009). Matka migrantka: Perspektywa transnarodowości w badaniu przemian ról rodzicielskich. Studia Migracyjne - Przegląd Polonijny, (1), 61-84.

Urbańska, S. (2015). Matka Polka na odległość: Z doświadczeń migracyjnych robotnic 1989-2010. Toruń: Wydawnictwo UMK. (Monografie FNP, Seria humanistyczna)

Urry, J. (2000). Sociology beyond societies: Mobilities for the twenty-first century. London-New York: Routledge.

Urry, J. (2007). Mobilities. Cambridge: Polity Press.

Vertovec, S. (2001). Transnationalism and identity. Journal of Ethnic and Migration Studies, 27(4), 573-582. http://dx.doi.org/10.1080/13691830120090386

Vertovec, S. (2009). Transnationalism. London: Routledge.

Wallace, C. D. (2002). Opening and closing borders: Migration and mobility in East-Central Europe. Journal of Ethnic and Migration Studies, 28(4), 603-625. http://dx.doi. org/10.1080/1369183021000032227

Wallace, C. D., \& Stola, D. (2001). Patterns of migration in Central Europe. Basingstoke: Palgrave Macmillan. http://dx.doi.org/10.1057/9780333985519

White, A. (2014). Double return migration: Failed returns to Poland leading to settlement abroad and new transnational strategies. International Migration, 52(6), 72-84. http:// dx.doi.org/10.1111/imig.12138

Zontini, E. (2004). Immigrant women in Barcelona: Coping with the consequences of transnational lives. Journal of Ethnic and Migration Studies, 30(6), 1113-1144. http:// dx.doi.org/10.1080/1369183042000286278 